\title{
KAJIAN STRUKTUR BATIN DALAM LIRIK LAGU PENYANYI TULUS
}

\author{
Thomas Eurisco Samson \\ Falantino Eryk Latupapua \\ Merlyn Rutumalessy \\ Email : milanozeth@gmail.com
}

\begin{abstract}
ABSTRAK: Penelitian tentang struktur batin dalam lirik lagu penyanyi Tulus telah dilakukan. Tujuan penelitian ini adalah untuk menganalisis struktur batin pada lirik lagu penyanyi Tulus. Penelitian ini menggunakan metode deskriptif kualitatif. Sumber data penelitian adalah tujuh lirik lagu penyanyi Tulus, yakni; (1) Gajah, (2) Jangan Cinta Aku Apa Adanya, (3) Untuk Matahari, (4) Sewindu, (5) Manusia Kuat, (6) Teman Hidup, dan (7) Satu Hari Di Bulan Juni. Pengumpulan data dilakukan melalui teknik simak dan catat. Hasil penelitian menunjukkan bahwa struktur batin berdasarkan tema, rasa, nada, dan amanat, pada kumpulan lirik lagu tulus, memiliki makna yang terdapat adalah hidup tidak selamanya sesuai dengan apa yang kita harapkan, dan tidak semua perjuangan yang kita perjuangkan akan berhasil. Kita harus mempunyai komitmen atau tekad yang kuat untuk membuktikan pada dunia bahwa kita berhasil meraih masa depan kita.
\end{abstract}

Kata kunci: struktur batin, lirik lagu, penyanyi Tulus. 
STUDY OF INNER STRUCTURE

IN LIRIC SONG OF TULUS SINGER

\author{
Thomas Eurisco Samson \\ Falantino Eryk Latupapua \\ Merlyn Rutumalessy \\ Email : milanozeth@gmail.com
}

\begin{abstract}
The purpose of this study was to analyze the inner structure of the song lyrics of Singer Tulus. This study used descriptive qualitative method. The source of research data is the seven song lyrics of Singer Tulus, namely; (1) Elephants, (2) Don't Love Me Is It, (3) For the Sun, (4) Missing, (5) Strong Man, (6) Life Friend, and (7) One Day in June. Data collection is done through techniques refer to and record. The results showed that the inner structure based on themes, tastes, tones, and mandates, in a collection of sincere song lyrics, having meaning contained is that life is not always in accordance with what we expect, and not all the struggles we strive for will succeed. We must have a strong commitment or determination to prove to the world that we have achieved our future.
\end{abstract}

Keywords: inner structure, song lyrics, Tulus singers. 


\section{A. PENDAHULUAN}

Puisi adalah bagian dari karya sastra yang dapat dikaji dari bermacam-macam aspek, misalnya struktur dan unsur-unsurnya, mengingat puisi merupakan struktur yang tersusun dari bermacam-macam unsur dan sarana-sarana kepuitisan (Pradopo, 1990:3). Puisi juga merupakan sebuah gambaran atas cerminan hidup manusia yang dituangkan penyair dalam karyanya. Puisi ditulis atau diciptakan sebagai hasil kreativitas penyair, bertujuan untuk dibaca atau dinikmati oleh pembaca. Penyampaian puisi dalam bentuk apapun juga bertujuan agar puisi itu dapat berkomunikasi dengan pembaca atau audience.

Dengan melihat uraian di atas, unsur-unsur dalam puisi dapat juga ditemukan dalam lirik lagu. Lirik mempunyai dua pengertian yaitu (1) karya sastra (puisi) yang berisi curahan perasaan pribadi, (2) susunan sebuah nyanyian (Moeliono, 2003:678). Dalam menggunakan lirik seorang penyair atau pencipta lagu itu harus benar-benar pandai mengolah kata.

Dari penjelasan mengenai lirik dan lagu, maka dapat disimpulkan bahwa lirik lagu adalah karya sastra (puisi) yang berisi curahan perasaan pribadi atau suasana kata sebuah nyanyian. Lirik lagu merupakan ekspresi seorang tentang suatu hal yang sudah dilihat, didengar maupun dialaminya. Dalam mengekspresikan pengalamannya, pencipta lagu melakukan permainan kata-kata dan bahasa untuk menciptakan daya tarik dan kekhasan terhadap lirik atau syair lagunya tersebut. Lirik lagu juga terbentuk dari bahasa yang dihasilkan dari komunikasi antara pencipta lagu dengan masyarakat penikmat lagu. Lirik lagu merupakan ekspresi seseorang dari dalam batinnya tentang sesuatu hal baik yang sudah dilihat, didengar maupun dialami. 
Alasan peneliti memilih penyanyi Tulus dalam penelitian ini, karena Tulus merupakan salah satu komposer dan penyanyi muda yang berbakat yang berhasil dengan karya-karyanya. Jujur dalam bermusik merupakan sebuah senjata untuk menembus hati pendengarnya. Kejujuran dalam menciptakan baris-baris lirik yang dibalut melodi dan dinyanyikan dengan jiwa dengan memberikan getaran yang berbeda https://www.hipwee.com/list/6-hal-kenapa-tulus-layak-dijadikan-sebagai penyanyi-idola (diakses pada tanggal 20 Juli 2018, pukul 11:05 wit).

Pada penelitian ini juga, peneliti memilih tiga album dari penyanyi Tulus yaitu album Gajah yang terdapat lagu Gajah, Jangan Cintai Aku Apa Adanya, Lagu Untuk Matahari, dan Satu Hari di Bulan Juni. Album TULUS yang terdapat lagu Sewindu dan Teman Hidup dan album Monokrom yang terdapat lagu Manusia Kuat. Alasannya karena peneliti hanya tertarik dengan ketujuh lirik lagu tersebut.

Keistimewaan dari ketujuh lirik lagu "Gajah”, “Jangan Cintai Aku Apa Adanya", "Lagu Untuk Matahari”, "Sewindu”, "Manusia Kuat, "Teman Hidup" dan "Satu Hari di Bulan Juni" adalah terdengar ringan dan mudah dinikmati serta menyiratkan pemberontakan dan pembuktian diri. Dalam lirik lagu tersebut ada banyak momen perjalanan karir yang tersirat jelas. Tulus berhasil menajamkan kemampuannya memotret kisah sederhana dengan sudut pandang yang tidak sederhana, sehingga membuat lagu-lagunya berbeda dan tetap mempunyai lacakan jejak yang khas.

Dalam penelitian ini, peneliti menggunakan kajian struktur batin dikarenakan, pertama, apabila ditinjau dari sisi maknanya, struktur batin adalah hal pokok yang terpenting dalam membangun lirik lagu. Untuk memahami sebuah lirik lagu harus memahami struktur batinnya. Kedua, nilai keindahan yang terkandung dalam sebuah 
lirik lagu dapat dilihat dari strukturnya, dalam penelitian ini struktur batin termasuk struktur dalam lirik lagu. Ketiga, akan memudahkan pembaca memahami sebuah lirik lagu dengan melihat dari struktur batinnya. Keempat, pembelajaran mengenai struktur batin berkaitan dengan pembelajaran apresiasi karya sastra.

Dalam penelitian ini, peneliti menganalisis struktur batin menyangkut tema, rasa, nada dan amanat dalam lirik lagu dari penyanyi Tulus yaitu lirik lagu "Gajah”, “Jangan Cintai Aku Apa Adanya”, "Lagu Untuk Matahari”, “Sewindu”, “Manusia Kuat, "Teman Hidup" dan "Satu Hari di Bulan Juni".

\section{B. METODE PENELITIAN}

Dalam penelitian ini, peneliti menggunakan pendekatan kualitatif. Menurut Denzin dan Lincoln (dalam Moleong, 2012:5), penelitian kualitatif adalah penelitian yang menggunakan latar alamiah dengan maksud menafsirkan fenomena yang terjadi dengan melibatkan berbagai metode yang ada. Jadi, dalam penelitian ini peneliti mendeskripsikan secara alamiah data dari proses interaksi dengan objek yang diteliti yaitu lirik lagu penyanyi Tulus. Penelitian ini bersifat deskriptif, yaitu memberikan gambaran secara jelas tentang bagaimana struktur batin dalam lirik lagu penyanyi Tulus.

\section{PEMBAHASAN}

\section{Struktur Batin dalam Lirik Lagu „Gajah}

\section{a) Tema}

Lirik lagu Gajah bertemakan tentang perjuangan. Dapat dibuktikan pada kutipan lirik lagu di bawah ini : 
Kau temanku kau doakan aku

Punya otak cerdas aku harus sanggup

Kutipan penggalan lirik lagu di atas menjelaskan tentang perjuangan penyair yang mengubah ejekan atau hinaan dari teman-temannya menjadi semangat dan motivasi baginya untuk meraih mimpi-mimpi.

\section{b) Nada dan Suasana}

Nada yang terdapat dalam lirik lagu Gajah yaitu nada marah. Hal tersebut dapat dilihat pada kutipan berikut:

\section{Waktu kecil dulu mereka menertawakan Mereka panggilku gajah, ku marah}

Kutipan di atas menunjukkan nada marah karena sejak kecil, penyanyi (Tulus) dipanggil gajah oleh teman-temannya karena ia berbadan besar. Meski ia dibully, dihina, dan dicerca dengan gencar oleh teman-teman yang membencinya, ia tidak perlu takut apalagi sampai depresi. Ia berusaha sabar dan tabah dan lihat segalanya dari sisi positifnya.

\section{c) Perasaan}

Pada lirik lagu Gajah, rasa yang diekspresikan penyair yaitu rasa bersyukur.

Hal tersebut dapat dilihat pada kutipan berikut:

Kini ku beri ta $k$ bisa jadi yang terbaik

Yang terburuk kelak hu puji dalam olokan

Mereka ingatku marah

Jabat tangganku panggil aku gajah

Kau aku harus sanggup

Bila jatuh gajah lain membantu

Yang terburuk kela temanku kau doakan aku

Punya otak cerdas bisa jadi yang terbaik 
Kutipan-kutipan di atas menunjukkan perasaan bersyukur yang disampaikan penyanyi (Tulus) bahwa ketika hinaan datang padanya, serta sakit hati yang ia rasakan. Namun ia tidak pernah jadikan hal tersebut sebagai beban yang menghambatnya untuk maju dan terus berkembang. Ia berpikir bahwa ia boleh dihina dan boleh sakit hati sekarang, namun ia jadikan semua itu sebagai pemicu semangatnya.

\section{d) Amanat}

Amanat atau pesan yang yang tersirat dalam lirik lagu Gajah yaitu sebagai berikut:

1. Tidak ada guna untuk terus memikirkan masa lalu, tetapi lebih baik memikirkan untuk bangkit merahi impian di masa depan.

2. Jika saat kita sedang dalam masa yang sulit, janganlah kita berkecil hati. Kita harus ingat bahwa mereka yang menjatuhkan kita belum tentu bisa berhasil seperti kita yang jauh lebih baik. Tetaplah fokus pada tujuan yang kita tujuh.

\section{Struktur Batin dalam Lirik Lagu "Jangan Cintai Aku Apa Adanya"}

\section{a) Tema}

Tema yang terdapat pada lirik lagu Jangan Cintai Aku Apa Adanya yaitu tentang keinginan seseorang untuk berubah. Dapat dilihat pada lirik lagu di bawah ini: 
Kutipan di atas menggambarkan sang penyanyi (Tulus) menuntut pada pasangannya bahwa jangan mencintainya apa adanya. Karena apabila terus-menerus dengan keadaan seperti ini, maka sang penyanyi (Tulus) tidak akan berubah atau berkembang. Dan dia tidak mau seperti itu.

\section{b) Nada dan Suasana}

Nada adalah sikap penyair terhadap pembacanya. Nada sering kali dikaitkan dengan suasana. Nada yang terdapat dalam lirik lagu Jangan Cintai Aku Apa Adanya yaitu nada berupa sebuah keinginan. Hal tersebut dapat dilihat pada kutipan berikut:

\section{Aku ingin lama jadi petamu}

aku ingin jadi jagoanmu

Kutipan di atas menggambarkan setiap orang pasti menginginkan suatu hubungan yang berlangsung lama bahkan untuk selamanya. Sama halnya dengan kedua kalimat di atas yang disampaikan penyanyi (Tulus) pada wanita pujaannya yaitu ia ingin menjadi "peta" dan "jagoan" bagi kekasihnya. "Peta" Apa gunanya? Ketika kita sedang melakukan perjalanan terkadang kita membutuhkan peta dan menggunakannya sebagai petunjuk jalan. Hal ini penyanyi (Tulus) menegaskan kepada kekasihnya agar tuntutlah sesuatu hal, di mana Tulus dan kekasihnya saling memberikan petunjuk dan arahan yang baik. Mampu menjadi pegangan dalam perjalanan cinta. Tulus dan kekasihnya saling mengingatkan dan merencakan bersama untuk mereka. Kata "jagoan" digambarkan penyanyi (Tulus) ingin menjadi penjaga atau pelindung bagi sang kekasih. 


\title{
c) Perasaan
}

Pada lirik lagu Jangan Cintai Aku Apa Adanya, perasaan yang diekspresikan penyair yaitu perasaan jenuh dan bosan. Hal tersebut dapat dilihat pada kutipan berikut.

\author{
Kau terima semua kurangku \\ Kau tak pernah marah bila ku salah \\ Engkau selalu memuji apapun hasil tanganku \\ Yang tidak jarang payah \\ Jangan cintai aku apa adanya, jangan \\ Tuntutlah sesuatu biar kita jalan ke depan
}

Kutipan di atas menunjukkan penyanyi (Tulus) merasa jenuh dan bosan karena sang kekasih selalu memuji apa yang dia lakukan, walaupun hasilnya yang tidak memuaskan. Sang kekasih tidak pernah marah ketika penyanyi (Tulus) melakukan kesalahan, karena sang kekasih menerima semua kekurangan penyanyi (Tulus) tersebut.

\section{d) Amanat}

Amanat atau pesan yang yang tersirat dalam lirik lagu Jangan Cintai Aku Apa Adanya yaitu sebagai berikut:

1. Sepasang kekasih haruslah saling mendukung satu sama lain. Hubungan yang saling membangun dan mendukung akan membuat kita semakin kuat. Jangan membiarkan pasangan kita begitu-begitu saja, tetapi tuntunlah dia sehingga ia dapat mengubah hidup kearah yang lebih baik. 


\section{Struktur Batin dalam Lirik Lagu 'Lagu Untuk Matahari”}

\section{a) Tema}

Tema yang terdapat pada lirik lagu Lagu Untuk Matahari yaitu tentang perjuangan seseorang yang mengubah ejekan atau hinaan menjadi semangat dan motivasi ke depan untuk merahi mimpi-mimpi. Dapat dilihat pada bait ketiga lirik lagu di bawah ini:

(menari, bernyanyi) lakukan yang kau suka (hidupmu) bukan hidupnya

Kutipan di atas menggambarkan tekad kuat Tulus yang ingin mengubah ejekan atau hinaan orang kepadanya dengan belajar hingga merahi mimpi-mimpinya. Kehidupannya tidak akan sama dengan kehidupan orang lain. Lewat kutipan tersebut Tulus mau menunjukkan bahwa dia bisa ketika orang lain meremehkannya. Ia tidak akan malu ataupun tidak percaya diri. Sebab ia akan berhasil sukses dengan hasil kerjanya sendiri.

\section{b) Nada}

Nada yang terdapat dalam lirik lagu Lagu Untuk Matahari yaitu nada menasihati dan ajakan. Hal tersebut dapat dilihat pada kutipan berikut:

Patah kadang semangat

dengar mulut pedas berdebat

yang hanya lihat salahmu

Gerah kadang pendengar

dapat cibiran sang benar

Sinisme bukan untukmu

oo... 
Kutipan di atas menasihati kita agar tidak terlalu memusingkan omongan orang lain, apa lagi sindiran, olokan, yang keluar dari mulut orang lain kepada kita. Meski kadang mematahkan semangat, membuat telinga gerah tapi tidak perlu kita menanggapinya.

\section{c) Perasaan}

Pada lirik lagu untuk matahari, rasa yang diekspresikan penyair yaitu rasa semangat. Hal tersebut dapat dilihat pada kutipan berikut:

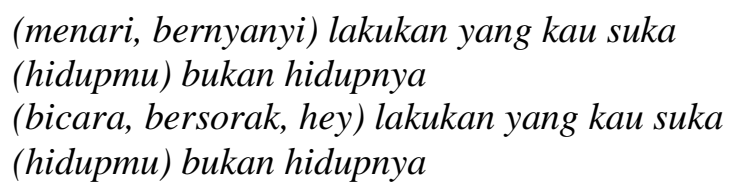

Kutipan di atas menggambarkan tekad kuat Tulus yang ingin mengubah ejekan atau hinaan orang kepadanya dengan belajar hingga merih mimpi.

\section{d) Amanat}

Amanat yang terdapat pada lirik lagu ini yaitu sebagai berikut.

1. Jangan pedulikan mereka yang membenci kita.

2. Apapun omongan orang yang negatif terhadap kita, abaikan!. Karena yang jalani dan yang tahu sifat asli diri kita cuma kita sendiri.

\section{Struktur Batin dalam Lirik Lagu Sewindu}

\section{a) Tema}

Tema yang terdapat pada lirik lagu Sewindu yaitu tentang patah hati. Dapat dilihat pada kutipan di bawah ini: 
Sudah sewindu ku di dekatmu

Sesaat dia datang pesona bagai pangeran

Dan beri kau harapan bualan cinta di masa depan

Dan kau lupakan aku semua usahaku

Kutipan di atas menggambarkan proses panjang mencintai dan mendapatkan seseorang. Selama 8 tahun, digambarkan bagaimana seorang pria bersabar demi mendapatkan hati wanita yang diidamkan. Tapi setelah perjuangan sekian lama, pria itu harus menerima kenyataan bahwa wanita yang ia cinta memilih pria lain

\section{b) Nada}

Nada yang terdapat dalam lirik lagu Sewindu yaitu nada berupa kesal. Hal tersebut dapat dilihat pada kutipan berikut:

Oh tak akan lagi ku menemuimu di depan pintu

Dan tak ada lagi tutur manis ku merayumu

Kutipan di atas menunjukkan rasa kekesalan sang lelaki kepada si gadis yang selama delapan tahun mereka bersama-sama. Hal ini dikarenakan wanita tersebut lebih memilih pria lain, membuat si sang lelaki ini berjanji dalam dirinya untuk tidak akan lagi bertemu si wanita. Apalagi berbicara dengan wanita tersebut, itu tidak akan lagi.

\section{c) Perasaan}

Pada lirik lagu Sewindu, perasaan yang diekspresikan penyair yaitu jatuh cinta dan patah hati. Hal ini dapat dilihat pada kutipan berikut.

Tak mungkin bila engkau tak tahu

Bila ku menyimpan rasa yang ku benam sejak lama 
Perasaan patah hati digambarkan pada kutipan di atas ditunjukkan seorang pria yang telah lama menyimpan perasaan cinta pada seorang wanita. Perasaan yang membuatnya rela menunggu hingga delapan tahun atau sewindu. Namun nyatanya perasaan itu hancur seketika ketika sang wanita telah menemukan pangeran baru di hatinya. Kalah tentu menyakitkan hati. Tapi pengalaman perih itu memberinya pelajaran untuk kelak tidak berbuat bodoh lagi. Cukuplah sekali salah tujuan dalam menitipkan hati. Kini saatnya memulai perjalanan baru lagi.

\section{d) Amanat}

Amanat yang terdapat dalam lirik lagu Sewindu adalah sebagai berikut:

1. Cinta tidak seharusnya memiliki. Jadi tetap sabar dan bersyukur

2. Jangan memendam perasaan ketika mencintai seseorang, karena kita akan menyesalinya saat ia lebih memilih orang lain

3. Patah hati memang mengirim nyeri sampai ke ulu hati, tapi gagal dalam cinta tidak harus membuat kita hancur.

4. Hadapilah realita kehidupan ini dengan jiwa yang gagah berani. Biarkan luka itu menyayat jiwa kita. Kita telah mengalami sebuah pengalaman yang sangat menggetarkan.

\section{Struktur Batin dalam Lirik Lagu Manusia Kuat}

\section{a) Tema}

Tema yang terdapat pada lirik lagu Manusia Kuat adalah tekad yang kuat untuk meraih mimpi. Dapat dilihat pada kutipan di bawah ini: 
Kutipan di atas menunjukkan tekad yang sungguh-sungguh oleh penyanyi bahwa seseorang tidak dapat menghalanginya untuk meraih cita-citanya. Walaupun kakinya di patahkan, tangannya dilumpuhkan, bahkan senyumnya direbut. Namun semua itu tidak membuatnya patah semangat dan berhenti. Akan tetapi hal itu membuatnya terus berjuang hingga mendapatkan apa yang ia impikan.

\section{b) Nada}

Nada yang terdapat dalam lirik lagu Manusia Kuat yaitu nada tegar. Hal tersebut dapat dilihat pada kutipan berikut :

Kau bisa Patahkan kakiku

Patah tangan Rebut senyumku

Hitamkan Putihnya hatiku

Tapi tidak mimpi-mimpiku

Jelas sekali kekuatan semangat optimisme disuarakan oleh musisi Tulus. Pada kutipan di atas, Tulus seakan ingin mengatakan pada pecinta musik bahwa rintangan yang berbentuk berbagai kesulitan tak jarang melumpuhkan kita. Diri bisa menjadi terpuruk dan menyerah kalah tetapi semangat boleh terus berkobar.

\section{Kau bisa patahkan kakiku}

Kau bisa lumpuhkan tanganku

Namun, ketika kita yakin itu semua adalah batu ujian yang justru akan menguatkan tekad untuk maju, segalanya akan teratasi. Ini secara langsung terungkap dalam baris: Tapi tidak mimpi-mimpiku. Terkadang hidup memang tak sesuai dengan apa yang diangankan. Kenyataan bisa bertolak belakang dengan keinginan. Akan tetapi, manakala kita mampu bangkit dari beban perasaan kecewa yang menindih jiwa, segalanya akan normal kembali. Hati yang sebelumnya terasa 
perih, perlahan terobati. Roman wajah yang tampak kecut, mulai melukiskan senyum kembali. Dalam lagu ini, Tulus dengan gaya puitik nan lugas mengatakan:

Kau bisa merebut senyumku

Tapi sungguh tak akan lama

Kau bisa merobek hatiku

Tapi aku tahu obatnya

Musisi seperti Tulus menggambarkannya dengan lebih gamblang dalam lagu Manusia Kuat. Ia uraikan bahwa orang akan lebih menghargai nilai diriya ketika dia mampu berdiri lagi setelah berkali-kali jatuh terpuruk dalam kegagalan. Baginya justru karena pernah gagal, orang akan menjadi invididu kuat dan berjiwa teguh-diri yang bernilai.

\section{c) Perasaan}

Perasaan yang di ekspresikan penyanyi yaitu perasaan semangat dilihat dalam lirik lagu berikut :

\section{Manusia manusia kuat itu kita}

Jiwa jiwa yang kuat itu kita

Perasaan yang terdapat pada lirik lagu Manusia Kuat yaitu perasaan semangat. "Manusia Kuat" adalah judul lagu yang ditulis oleh Tulus, dan merupakan bagian dari album Monokrom. Lagu ini adalah seruan untuk pantang menyerah, dan tentang semangat hidup. Lagu ini bercerita tentang jiwa, yang merupakan kekuatan besar dalam raga manusia. Jiwa merupakan bagian tidak tersentuh, yang tetap bisa berlari kencang walau raga mungkin lumpuh. Lewat lagu ini Tulus juga menyerukan keyakinannya bahwa tidak ada satu manusia pun yang bisa benar-benar mematahkan langkah baik manusia lain. 


\section{d) Amanat}

Amanat yang terdapat pada lirik lagu Manusia Kuat adalah sebagai berikut:

1. Lagu ini mengingatkan bahwa pengalaman buruk justru memberi kita kesempatan untuk membuktikan diri, menjadi manusia yang berbesar hati tidak akan membuat kita merugi.

2. Harus pantang menyerah menghadapi problematika kehidupan dan ketika bermimpi kita tidak memberikan kesempatan pada seorang pun untuk mematahkan mimpi-mimpi kita.

3. Tidak ada gunanya mengurung diri karena kehidupan yang buruk, lebih baik bangkit dan maju.

Lirik- lirik dalam lagu ini mengandung ajakan kepada manusia- manusia agar semangat dan meningkatkan kepercayaan diri ketika bermimpi.

\section{Struktur Batin dalam Lirik Lagu "Teman Hidup”}

\section{a) Tema}

Tema yang terdapat pada lirik lagu Teman Hidup yaitu tentang kesetiaan.

Dapat dilihat pada bait ketiga lirik lagu di bawah ini:

Kau punya aku, ku punya kamu, selamanya kan begitu

Kutipan baris keenam belas di atas menggambarkan kesetiaan dua insan manusia yang sanggup bertahan dalam kesederhanaan hingga usia mereka yang sudah tak lagi muda, karena mereka tetap berkomitmen bahwa mereka saling memiliki, dan selamanya tetap seperti itu. 


\section{b) Nada dan Suasana}

Nada yang terdapat dalam lirik lagu Teman Hidup yaitu nada mengajak. Hal tersebut dapat dilihat pada kutipan berikut:

\section{Bila di depan nanti}

Banyak cobaan untuk kisah cinta kita

Jangan cepat menyerah

Kutipan di atas menggambarkan penyanyi mengajak pasangan hidupnya agar tetap tabah dan sabar. Ketika ada masalah yang datang menimpah hubungan mereka dan seberat apapun cobaan yang menerpa hubungan mereka, penyanyi berharap agar kekasihnya jangan cepat menyerah.

\section{c) Perasaan}

Perasaan yang terdapat pada lirik lagu Teman Hidup yaitu rasa bahagia. Perasaan bahagia akan dirasakan apabila seseorang merasa bahagia dan senang itu berarti ada suatu hal yang menyenangkan hatinya. Orang biasanya merasa gembira apabila mendapatkan hal yang baik dalam hidupnya, atau mendapati bahwa harapannya terkabul sesuai dengan apa yang dia inginkan sejak awal atau mendapatkan hal yang menjadi tujuannya. Hal tersebut dapat dilihat dalam kutipan berikut:

Dia indah meretas gundah

Dia yang selama ini ku nanti

Membawa sejuk, memanja rasa

Dia yang selalu ada untukku

Di dekatnya aku lebih tenang

Kutipan di atas menggambarkan perasaan penyanyi yang senang melihat kecantikan sang kekasihnya. Ketika melihat kemolekan kekasihnya membuat masalah-masalah yang dialami atau dihadapi penyanyi menjadi hilang. Bagi 
penyanyi, ia merasa lebih tenang, senang, bahkan kehidupannya lebih berarti jika ia berada di dekat kekasihnya. Karena semua yang dia inginkan, diharapkan, dan dinantikan selama ini adalah kekasihnya ini.

Bersamanya jalan lebih terang

Tetaplah bersamaku jadi teman hidupku

Berdua kita hadapi dunia

Kau milikku ku milikmu kita satukan tuju

Bersama arungi derasnya waktu

Kau milikku, ku milikmu

Kau milikku, ku milikmu

Kutipan di atas menjelaskan bahwa penyanyi mengungkapkan perasaan bahagia yaitu ia merasa kehidupannya sudah lebih terang saat bersama-sama kekasihnya. Ia meminta kepada kekasihnya agar mau tetap menemaninya habiskan hidup bersama-sama.. Untuk itu, penyanyi meminta agar dalam keadaan susah atau pun senang yang akan mereka hadapi. Hadapilah sama-sama karena mereka adalah satu.

\section{d) Amanat}

Amanat atau pesan yang yang tersirat dalam lirik lagu Teman Hidup yaitu sebagai berikut:

1. Ketika ada masalah, janganlah kita cepat menyerah

2. Kesetiaan dapat diuji pada saat kita mampu melewatinya bersama-sama.

\section{Struktur Batin dalam Lirik Lagu "Satu Hari Di Bulan Juni"}

\section{a) Tema}

Tema yang terdapat pada lirik lagu Satu Hari Di Bulan Juni yaitu tentang percintaan. Dapat dilihat pada kutipan lirik lagu di bawah ini:

Rasakan ini senang di dadaku memilikimu 
Hidup memang tak selamanya bahagia. Saat sedang sedih, ada kalanya kita akan berpura-pura bahagia karena tidak ingin membuat orang lain khawatir. Akan tetapi, jika kita sedang bersama orang yang kita cintai, perasaan sedih itu seolah menguap begitu saja. Semua perasaan itu berganti menjadi sebuah kebahagiaan. Hal tersebut digambarkan pada kutipan di atas bahwa sang pria merasa senang bisa memiliki wanita pujaannya.

\section{b) Nada dan Suasana}

Nada adalah sikap penyair terhadap pembacanya. Nada sering kali dikaitkan dengan suasana. Nada yang terdapat dalam lirik lagu Satu Hari Di Bulan Juni yaitu nada pujian dan menasihati. Hal tersebut dapat dilihat pada kutipan berikut:

Kita tak perlu terlalu banyak uang

Kita bahagia meski tak kemana-mana

Kutipan di atas menunjukkan nada menasihati seorang pria pada pasangannya hidupnya bahwa jika di dunia ini kebahagian bisa didapat lewat hal yang sederhana, maka tidak perlu mengeluarkan uang yang begitu banyak. Kekayaan bukan hanya dihitung dari banyaknya uang yang kita miliki saja. Meski hidup sederhana, bila memiliki sedikit uang, kita bisa mendapatkan hidup yang lebih bahagia.

Senada dengan itu, nada dalam lirik lagu berupa nada pujian seorang lelaki pada wanita pujaannya. Hal ini dapat dilihat pada kutipan berikut:

\section{Kamu cantik (cantik) meski tanpa bedak}

Rasakan ini senang di dadaku memilikimu

Kutipan di atas menunjuk pada nada pujian seorang pria pada kekasihnya bahwa bisa memiliki wanita pujaannya adalah suatu kebanggaan tersendiri untuknya. Karena baginya, selain cantik, sang istri juga memiliki hati yang tulus. Ada orang 
cantik karena make up dan begitu dihapus, wajahnya berbeda. Tetapi sang pria di atas memuji kecantikan pujaan hatinya bahwa ia tetap cantik walau harus memakai bedak.

\section{c) Perasaan}

Pada lirik lagu Satu Hari Di Bulan Juni, perasaan yang diekspresikan penyair yaitu rasa bahagia. Hal tersebut dapat dilihat dalam kutipan berikut:

Peluk aku, merdu ku dengar debar jantungmu

Oh tenang sayang semua kan baik-baik saja

Kutipan di atas menjelaskan bahwa sang pria sangat bahagia memiliki sang pujaan hatin. Sang pria tersebut ingin memeluk wanitanya dan merasakan debar jantung yang dimiliki wanitanya itu. Ia ingin memastikannya bahwa wanitanya tetap tenang. Jangan takut karena semua akan baik-baik saja.

\section{d) Amanat}

Amanat atau pesan yang yang tersirat dalam lirik lagu Satu Hari Di Bulan Juni yaitu sebagai berikut:

1. Uang tidak ada apa-apanya dibandingkan dengan memiliki orang yang mencintai kita dengan ketulusan hati.

2. Jatuh cinta setiap hari pada hal yang ada di sekelilingmu akan membuatmu makin kaya. Karena kamu tidak bisa menukarkan rasa bahagianya saat jatuh hati dengan sejumlah materi.

3. Selalu mencintai pasangan dalam suka maupun kekurangan. 


\section{KESIMPULAN}

Hasil dari penelitian ini menyimpilkan bahwa ketujuh lirik lagu pada album Gajah, Tulus dan Monojrom menghasilkan temuan struktur batin yaitu (1) tema, yang terdiri atas: (a) perjuangan, (b) keinginan untuk berubah, (c) memotivasi meraih mimpi, (d) patah hati, (e) tekat yang kuat, (f) kesetiaan, dan (g) percintaan. (2) Nada dalam lirik lagu yang terdiri atas: (a) marah, (b) memohon, (c) ajakan, (d) kesal, (e) tegar, (f) mengajak, dan (g) memuji. (3) perasaan dalam lirik lagu terdiri atas: (a) bersyukur, (b) jenuh, (c) bersyukur, (d) kesal, (e) tegar, (f) bahagia, (g) bahagia. (4) amanat dalam lirik lagu terdiri atas; (a) jangan mudah menyerah, (b) saling mendukung, (c) jangan peduli mereka yang membenci kita, (d) cinta tak seharusnya memiliki, (e) tetap semangat meraih mimpi, (f) jangan menyerah ketika ada masalah, (g) selalu mencintai dalam suka maupun duka.

\section{E. DAFTAR PUSTAKA}

https://www.hipwee.com/list/6-hal-kenapa-tulus-layak-dijadikan-sebagai penyanyiidola (diakses pada tanggal 20 Juli 2018, pukul 11:05 wit).

Moleong. 2012. Metodologi Penelitian Kualitatif. Bandung Remaja Rosdakarya.

Pradopo, Rachmat Djoko. 1990. Pengkajian Puisi. Yogyakarta: Gadjah Mada University 
Kajian Struktur Batin Dalam Lirik Lagu Penyanyi Tulus 